\title{
Juridical Study of the Execution of Patent Objects as Fiduciary Guarantee
} Jeane Neltje Saly ${ }^{1 *}$, Gunardi Lie ${ }^{1}$, Mariske Myeke Tampi ${ }^{1}$, Yuniar Rahmatiar ${ }^{2}$, Suryono Sanjaya ${ }^{2}$, Adriel Michael Tirayo ${ }^{2}$

${ }^{1}$ Faculty of Law, Tarumanagara University, Letjen S. Parman Street Number 1, West Jakarta, Indonesia

${ }^{2}$ Faculty of Law, Universitas Islam As Syafiyah

$\begin{array}{ll}\text { DOI:10.36348/SJHSS.2019.v04i09.005 } & \text { | Received: } 13.09 .2019 \text { | Accepted: 20.09.2019| Published: } 30.09 .2019\end{array}$

*Corresponding author: Jeane Neltje Saly

\section{Abstract}

Problematics of the execution of patent object which are technological products as fiduciary guarantees is the impact of disorderly attitude by the community in increasing added value and competitiveness when achieving development goals. It also arises from violations against Law No. 13 of 2016 about patent, ratification of TRIPs (Trade Related Aspect of Intellectual Property Rights), attachment to the rules of World Trade Organization (WTO). The problem is whether patent object can be used as a fiduciary guarantee and how positive law regulates the power of a fiduciary guarantee certificate in the execution. The research methods use a normative juridical method, by used secondary data obtained through study literature and analyzed qualitatively. The result and discussion of this research is that patent object can be used as a fiduciary guarantee and it can be executed if the debtor violate the agreement between parties, where the implementation of the execution is based on Article 29 paragraph 1 of Law No. 42 of 1999 about fiduciary guarantee. Also, the power of the fiduciary guarantee is the same as the court decision that has obtained permanent legal force if the agreement with fiduciary guarantee has been registered.

Keywords: Execution, Patent Object, Fiduciary Guarantees, Normative Juridical Method, ratification, permanent legal force.

Copyright @ 2019: This is an open-access article distributed under the terms of the Creative Commons Attribution license which permits unrestricted use, distribution, and reproduction in any medium for non-commercial use (NonCommercial, or CC-BY-NC) provided the original author and source are credited.

\section{INTRODUCTION}

Problematics of the execution of patent object as fiduciary guarantee is law enforcement against patent infringement in order to increase added value and competitiveness, an honest business and paying attention to people's importance in general[1]. These actions are based on the development of international trade followed by technological improvements, where Indonesia has ratified international trade rules [2], which are TRIPs (Trade Related Aspect of Intellectual Property Rights) [3], attachment to the rules of World Trade Organization (WTO).

The purpose of the establishment of WTO rules is the desire of developed countries to encourage members of countries in the world to obtain economic opportunities from improving technology through innovation, including patents. Therefore, it is desirable that the utilization be carried out maximally in any fields, in order to strengthen Indonesia's ability to face global competition.

However, this has not been achieved optimally. It can be seen in the cases that occurred, both internationally and nationally [4], such as
California, where Apple won a slide-to-unlock and quick link patents over Samsung after undergoing a four years trial process. With this victory, the company made by Steve Jobs has the right to get royalties of US\$ 120 million or around $\mathrm{Rp} 1.6$ trillion. The Supreme Court of the United States said that they do not accept the appeal for the case that had been filed since 2014 and Samsung was declared to have violated both patents [5].

As is known, Karuna Sumber Jaya Limited Liability Company was sued by 17 related companies Patent No. IDP0031670 regarding 'Packaging Wood Preservation Method with Expired Control'. Some of the companies that sued include Gaya Sukses Mandiri Kaseindo, Karsa Mitra Suksesindo and Kemas Kayu Indonesia limited liability companies [6] to Central Jakarta District Court. When sued by the companies above, patents have not been registered as guarantees.

Patents number ID P00201407545 with the inventor of the patent, Budi Santoso, founder and owner of PT Karuna Sumber Jaya, located in the Cileungsi area, Bogor, which manufactures and exports pallets from sengon wood raw material is motivated by mold problems when the pallet reaches the buyer. The trial of 
patent cases with case number 47/Pdt.SusHKI/Patent/2017/PN.Jkt.Pst was finally postponed, because the plaintiff's files were incomplete.

The trial was opened by the presiding judge Abdul Kohar at 14:40 WIB. The presiding judge immediately asked the plaintiffs to submit the company's legality documents in accordance with the trial agenda. However, it turned out that there was a lot of unpreparedness from the plaintiff. Two member judges, Tafsir Sembiring and Desbeneri Sinaga, also checked the files brought by the plaintiff. The plaintiff's mistake is that there are many files with no copies. Some other files actually don't have the original file. This makes the collection of files for legality checks of 17 companies invalid.

Plantation wood is less resistant to fungi than wood originating from the forest, such as when he took pallets from suppliers in Bengkulu. The problem made him think of finding a method of preserving plantation wood [7]. Together with seven LIPI researchers led by Prof. Sulaiman Yusuf, Budi conducted research for three years, with the object of trial and error being the product of his pallet. In 2006, Budi discovered a formula called Larutan 8 Dewa (L8D) which served to resist the attack of wood-destroying insects and fungi by a simple and environmentally friendly method.

At present, Karuna Sumber Jaya limited liability Company's pallet production capacity reaches 12,000 pallets per month. In addition, Karuna Sumber Jaya Limited Liability Company receives around 7,000 pallets from the outside for L8D coating. Budi's source of income is currently $80 \%$ comes from own pallet production and $20 \%$ comes from treatment pallets. From one factory, Budi is ready to add a new factory this year. He claimed to have owned an area of 6,000 $\mathrm{m} 2$ for his new factory. Budi intends to sell the L8D formula by giving training to prospective buyers first.

However, he hopes, before heading in that direction, the government through the Quarantine Hall can issue a certification for this pallet treatment profession so that its quality can be maintained and trusted. The lack of requirements that can win a lawsuit is that the patents for the export of timber are registered with the Fiduciary Institution as guarantees. Therefore, this case will result in not being confiscated as fiduciary guarantees and included in a criminal case of loss due to the incompatibility of the quality of exported wood.

\section{RESEARCH METHODS}

This paper uses a normative juridical method, which is to normatively examine the functions of Law Number 13 of 2016 concerning Patents. The data used in this study are secondary data obtained through data collection techniques, namely studies literature. The data obtained was analyzed qualitatively.

\section{RESULT AND DISCUSSION}

Fiduciary guarantees have been used in Indonesia since the Dutch colonial era, but because they are based on jurisprudence, so they do not guarantee legal certainty. Mochtar Kusumaatmadja [7] stated that in order to achieve order there is an effort to ensure legal certainty in human relations in the community, because it is impossible for humans to develop the talents and abilities where given by God optimally without order and legal certainty.

Normative aspects are the answer to legal certainty, because normative legal certainty is when a rule is made and declared in a certain way, because it regulates clearly and logically. Obviously in the sense that it does not cause doubt (multi- interpretation) and is logical in the sense that it becomes a norm system with other norms so that it does not clash or cause norm conflicts. Because norm conflicts resulting from rule uncertainty can take the form of norm consensus, norm reduction or norm distortion. Legal certainty refers to the enforcement of clear, permanent, consistent and consequent laws whose implementation cannot be influenced by subjective conditions.

Law No. 13 of 2016 about patents is made to replace Law No. 14 of 2001 about Patents that have no longer fulfilled the needs in the development of law, both nationally and internationally as a result of increasing technology in various fields so rapidly. Therefore, it is necessary to increase protection for inventors and patent holders. This is very important in order to motivate patent holders to improve their work, both in quantity and quality in order to encourage the welfare of the nation and the state to create a healthy business climate in global developments followed by technological improvements in the curret development period. Protection of works that are intellectual property provided by the state to investors for the results of their inventions in the field of technology has a strategic role in supporting nation-building and advancing public welfare.

Law No.13 of 2016 about Patents is expected to become an orderliness tool for patent holders and Inventors. This is according to Mochtar Kusumaatmadja's view that law is a tool for renewing society which is seen as absolute, in order to direct humans into the direction that desired by the law [8]. Law according to Sudikno is a whole set of rules or methods in a shared life that can be enforced with a punishment [9].

The term "patent" comes from English Language called "patent", starts from the term "patere" which means open up (to be known by the public), and "letters patent" which implies a decree issued by the kingdom to grant exclusive rights to individuals and certain business actors. Therefore, it can be said that the patent concept encourages inventors to introduce 
knowledge to the community which results in inventors obtaining exclusive rights within a certain period of time. Considering that the patent does not regulate who has to do an invention that is patented by a patent system is not considered a monopoly right [10].

Specified in Law No. 13 of 2016 that a Patent is an exclusive right granted by the state to the inventor for the results of his invention in the field of technology for a certain period of time implementing the invention himself or giving approval to other parties to implement it. Whereas Invention is an inventor's idea that is poured into a specific problem solve activity in the field of technology in the form of a product or process, or improvement and development of a product or process. While an Inventor is a person or several people who jointly carry out the ideas poured into activities which results in an invention.

Patents are territorial; it means that only binding in certain locations. In order to obtain patent protection in several countries or regions, someone must submit a patent application in each of these countries or regions. For Europe, one can submit a patent application to the European Patent Office [, if successful, the applicant will get multiple patents (up to 36 patents for each country in Europe).

Article 108 Law No. 13/2016 about Patents determine that patents can be used as objects of fiduciary guarantees. Execution of patents that are objects of fiduciary guarantees can be carried out if the debtor breaks the promise between parties. Patents that are object of fiduciary guarantees are not guarantees that are born under the law, but rather exist as a result of an agreement between creditors, namely a fiduciary guarantees institution with a debtor, namely a customer. From the view of the law, the binding of fiduciary guarantees is more specific, compared to guarantees born under the law, according to the norms in Article 1131 of the Civil Code. If the debtor does not fulfill the clause in the agreement, the debtor neglect. Fiduciary guarantees execution is the last step taken by creditors as fiduciary recipients. Fiduciary guarantees are born to complement the weakness of the guarantees of mortgage [11].

Fiduciary is the transfer of ownership rights of an object on the basis of trust provided that the object whose ownership rights are transferred remains within the control of the owner of the object. According to Article 1 Number 1 of Law No. 42 of 1999 about Fiduciary Guarantees, that fiduciary is the transfer of ownership rights of an object on the basis of the belief that objects whose ownership rights are transferred remain in the possession of the owner of the object.

After the enactment of Law Number 13 of 2016 about Patents, objects that become fiduciary objects are not only in the form of tangible objects, such as objects in inventory, merchandise, receivables, machine tools, or motorized vehicles [12], but also immovable tangible objects can be a fiduciary object, such as patents. Law Number 13 of 2016 Patents replace Law Number 14 of 2001 concerning Patents useful for business independence in the development of globalization followed by technological improvements. This was taken into consideration by the amendment of the Law No. 13/2016 about Patents as described in the Considering, that:

"That patents are intellectual property given by the state to inventors for the results of their inventions in the field of technology which have a strategic role in supporting national development and advancing public welfare; for technological developments in various fields so rapidly that it is necessary to increase protection for inventors and patent holders. Increasing patent protection is very important for inventors and patent holders because it can motivate inventors to improve their work, both in quantity and quality to encourage the welfare of the nation and state and create a healthy business climate."

There are several disadvantages of fiduciary guarantees, among other things, is that the recording of fiduciary objects based on the Fiduciary Guarantees Law is still considered unable to provide certainty about execution. The reason is that there is no particular mechanism for knowing the transfer of fiduciary objects to third parties, fourth and so on. Another problem is movable objects do not have strong ownership marks like immovable objects whose ownership must be marked with ownership certificates based on Article 616 Civil Code. The difference in these provisions clearly gives different consequences [13], where immovable objects will be difficult to be guaranteed again because everyone will see the ownership certificate and conversely moving objects will be very easy to move.

It can be said that the regulation about the ownership of the fiduciary object clearly causing complexity the process of executing fiduciary objects by creditors [14]. In fact, the document underlying the material agreement, both movable and immovable, is executorial or equivalent to the strength of a court ruling that has permanent legal force. Furthermore, in practice, it will cause problems in the implementation in the field of movable fiduciary objects. Because moving objects do not have certificates. According to Ricardo, the movement of movable objects do not have a basis of ownership in the form of certificates of rights will indeed be difficult to recognize in the field, especially if the goods have been moved or acquired [14]. If the 1977 Civil Code is linked to Article 1459 of the Civil Code which regulates the transfer of ownership rights of movable objects, it is clear that the transfer is based on the process of transferring control of the moving object. 
The problem is the fiduciary guarantees certificate still contains weakness. Therefore, it requires appropriate punishment in its violations, especially related to fiduciary moving objects. Given the amount of movable material used as a mechanism to support business people holding the greatest dominance, the recording mechanism must indeed be done as accurately as possible.

In order not to cause multiple interpretations, it is necessary to renew the Fiduciary Guarantees Law. The weakness of the Fiduciary Guarantees Law is also stated by Professor at the University of Indonesia, Rosa Agustina, said that in addition to the need for strict punishment on the transfer of objects which are objects of fiduciary guarantees without creditor permission, either in whole or in part, he also proposed arrangements for an electronic fiduciary registration system. So that the supervision of re-fiduciary fiduciary objects is clearly controlled in an official database of the fiduciary registration office.

In the terms of law enforcement, everyone always expects that the law can be established in the event of a concrete event, so that the event must not deviate and must be determined in accordance with existing laws, which in the end legal certainty can be realized. The importance of legal certainty in accordance with Article 28D paragraph 1 of the third amendment to the 1945 Constitution that "every person has the right to recognition, guarantee of protection and fair legal certainty and equal treatment before the law", which can be interpreted as the right to obtain the results of the execution, as long as it meets the specified requirements.

It was done based on the norms contained in Article 29 paragraph (1) of Law Number 42 of 1999 about Fiduciary Guarantees, that:

\section{Implementation of the Executorial Title}

Article 15 Paragraph (2) of the Fiduciary Guarantees Law states that a Fiduciary Guarantees Certificate has the same executorial power as a court decision that has obtained permanent legal force. What is meant by "executorial power" is directly carried out without going through a court and is final and binding on the parties to carry out the decision.

Fiduciary guarantees execution based on the executorial title contained in the Fiduciary Guarantees Certificate, the implementation must follow the procedure of implementing a court decision. If referring to the provisions contained in Article 196 of the Herzien Inlandsch Regulations (HIR), then the creditor must submit a request to the District Court to carry out the execution of the guarantees object based on the existing executorial title.
The head of the court then instructs the debtor to fulfill his obligations. If the specified maturity date has passed and the fiduciary provider has not fulfilled its obligations, based on Article 197 HIR, the head of the district court will order the bailiff to confiscate the object which is the fiduciary guarantees.

\section{Selling of Own Power through Public Auctions}

Article 15 Paragraph (3) of the Fiduciary Guarantees Law states, that "if the debtor is neglect, the fiduciary recipient has the right to sell the object which is the object of the fiduciary guarantees of his own authority", it means that creditors can carry out executions without involving the court or bailiff to make sales in public or auction.

In connection with the provisions contained in Article 29 Paragraph (1) Letter b of the Fiduciary Guarantees Law, which is the implementation of Article 15 Paragraph (3) of the Fiduciary Guarantees Law which states that "if the debtor is injured, the fiduciary has the right to sell the object of fiduciary guarantees on his own power. This can be interpreted as a creditor carrying out an execution that does not involve the court or bailiff to make sales in public or auction.

\section{Sales under the Hand}

Underhand sales are based on the agreement of the giver and recipient of the fiduciary and with this way the highest price can be obtained that gives the parties benefits. Underhand sales referred in the Fiduciary Guarantees Law causing the transfer of patents which and included in the form of written agreement. Patents can be used as objects of fiduciary guarantees, based on Article 5 Paragraph

Of the Law No. 42 of 1999 about Fiduciary Guarantees explains that the imposition of objects with fiduciary guarantees is made by notary deed in Bahasa.

Considering that the fiduciary guarantees agreement is an accesoir agreement of a principal agreement that creates an obligation for the parties to fulfill an achievement, especially an agreement with a registered fiduciary guarantees will have an executorial power similar to court decision that has obtained permanent legal force or in other words, it can be executed without a court decision (parate executie), because the Fiduciary Guarantees Certificate has an executorial title in the form of a sentence "FOR JUSTICE BASED ON THE BELIEFS IN THE ONE SUPREME GOD”, so that when the debtor neglect, the fiduciary recipient has the right to sell objects which are objects of fiduciary guarantees of their own power.

In accordance with what is referred to in Article 29 Paragraph (1) letter c of the Fiduciary Guarantees Law, for underhand sales is based on the agreement of the Fiduciary Giver and Recipient if in 
this way the highest price can be obtained by the parties as a benefit.

Underhand sales result in the transfer of rights to patents as stated in Article 74 paragraph (1) of the Patents Law, who explained that: Patents can be transferred either in whole or in part because:

- Inheritance;

- Grant;

- Will;

- Endowments;

- Written agreement; or

- Other reasons that are justified based on statutory provisions.

Furthermore, it should be noted that the execution of patents is charged with fiduciary guarantees. Based on Article 16 Paragraph (1) of the Presidential Regulation No. 37 of 2010 about Terms and Procedure for Recording Patents Transfer, recipients of patents due to the transitional written agreement must submit a request for registration of patents transfer to the Directorate General of Intellectual Property Rights, by attaching:

- Relevant Patents certificate;

- Written agreement regarding the transfer of Patent;

- Special Power of Attorney in the event that the application is submitted by proxy;

- The payment of the application for recording the transfer of patents; and

- Proof of annual patents fee payment

The requirement for these records is mandatory because patents are property rights granted by the state and their use with the implementation is limited to a certain period of time. If the transfer of patents is not recorded and announced in the General Register of Patents, it can result in non-binding to third parties in accordance with the provisions in Article 74 Paragraph (3) and Article 79 of Law No. 13/2016 about Patents.

\section{CONCLUTION}

Objects of patents can be used as fiduciary guarantees, and are executed if the debtor or fiduciary is violates the agreement, execution of patents which are objects of fiduciary guarantees can be carried out by means of Article 29 Paragraph (1) of Law No. 42/1999 about Fiduciary Guarantees, namely through Execution of Executorial Titles, Selling of Own Power through Public Auction, and Underhand Sales.

The strength of a fiduciary guarantees certificate is an accession agreement or a follow-up agreement of a principal agreement that creates an obligation for parties to fulfill an achievement on an agreement with a registered fiduciary guarantees that will have the same executive power as a court decision that has obtained permanent legal force or in other words, it can be executed without going through a court decision because the Fiduciary Guarantees Certificate has an executorial title in the form of a sentence " FOR JUSTICE BASED ON THE BELIEFS IN THE ONE SUPREME GOD", so that if the debtor neglect, the fiduciary has the right to sell objects which are objects of fiduciary guarantees of their own power.

\section{REFERENCES}

1. Badrulzaman, M. D. (1980). Aneka Hukum Bisnis. Bandung: Alumni.

2. Hartanto, H. (2019). https://sriright.wordpress.com/2018/02/ 27/patenmetode-pengawetan-kayu/. Jakarta.

3. Herzien Inlandsch Reglement/Reglemen Indonesia Baru (Stbl 1984: No. 16 yang diperbaharui dengan Stbl 1941 No. 44).Konsiderans Menimbang. Undang-Undang Nomor 13 Tahun 2016 tentang Paten.

4. Kanelo, T. (2004), Hukum Jaminan Fidusia Suatu Kebutuhan yang Didambakan, Bandung: Alumni.

5. Ketua Asosiasi Kurator dan Pengurus Indonesia (AKPI) Ricardo Simanjuntak, Diskusi PR Revisi UU Jaminan Fidusia. https://www.hukumonline.com/

berita/baca/lt5bf2b248083bc/ini-pr-besar-revi siuu- jaminan-fidusia/.

6. Kusumaatmadja, M. (1998). Fungsi Hukum Dalam Pembangunan Nasional. Bandung: Binacipta.

7. Kusumaatmadja, M. (2006). Pengantar Ilmu Hukum: Suatu Pengenalan Pertama Ruang Lingkup Berlakunya Ilmu Hukum. Bandung: Bin Cipta.

8. Mahbub, A. Apple Menang Hak Paten, Samsung Harus Bayar Rp. 1, 6 Triliun. https://tekno.tempo.co/ read/1031882/applemenang- hak-paten-samsung-haru s-bayar-rp-16triliun.

9. Nabila, A. 17 Perusahaan Gugat Hak Paten Pengawetan Kayu ke PN Jakpus. https://news.detik.com/berita/d-3668855/17perusaha an-gugat-hak-paten-pengawetan-kayuke- pn-jakpus.

10. Peraturan Presiden Nomor 37 Tahun 2010 tentang Syarat dan tata Cara Pencatatan Pengalihan Paten.

11. Prayudi, G. (2008). Jaminan dalam Perjanjian Utang Piutang. Yogyakarta: Merkid Press.

12. Ricardo. Kajian Perubahan UU No. 42 Tahun 1999 tentang Jaminan Fidusia, Focus Group Discussion.

https://www.hukumonline.com/berita/baca/lt5bf2b 2 48083bc/ini-pr-besar-revisi-uu-jaminan-fidusia/. Jakarta, 16 November.

13. Saly, J. N. (2016). Kajian Yuridis Hak Atas Paten Bukan Hak Monopoli, Semiloka Mahasiswa Pascasarjana UPN Veteran Cisarua.

14. Saly, J. N. (2018). Paper Dalam Rangka Seminar Perlindungan Invensi Dalam Perolehan Hak Paten, Fakultas Hukum Universitas Tama Jagakarsa. 
Jakarta, 13 November.

15. _ (2017). TRIPs dan Perlindungan Hak Cipta Dalam Penerapan, FGD, Pascasarjana Fakultas Hukum Universitas Pembangunan Veteran. Jakarta.

16. Sofwan, S. S. M. (1980). Beberapa Masalah Pelaksanaan Lembaga Jaminan Fidusia Di Dalam Praktik dan Perkembangan di Indonesia, Fakultas
Hukum UGM, Yogyakarta,

17. Sudikno. (2012). Fungsi Hukum Dalam Pelaksanaan Pembangunan Di Era Teknologi. Radja Grafindo.

18. Undang-Undang Nomor 13 Tahun 2016 tentang Paten.

19. Undang-Undang Nomor 42 Tahun 1999 tentang Jaminan Fidusia. 